\title{
BULLETIN of The BUSINESS, HISTORICAL SOCIETY
}

INCORPORATED

Vol. $X X, N o .6$

December, 1946

Whole No. 123

MEMBERS RECEIVE A NEW BOOK ON THE RADIO INDUSTRY

WAR AND BUSINESS : FOUR CENTURY-LONG STRUGGLES

N. B. S. Gras

“TRANSLATING” ECONOMIC POLICY INTO BUSINESS POLICY: AN ILLUSTRATION FROM THE RESUMPTION OF SPECIE PAYMENTS IN 1879

FRITZ REDLICH 


\title{
BUSINESS HISTORICAL SOCIETY, INC.
}

\author{
Organized in 1925 to promote the study \\ of business enterprise \\ from an historical point of view
}

\section{Officers}

JoHn W. HigGins, President

N. S. B. Gras, Vice-President

Allan Forbes, Treasurer

Arthur H. Cole, Librarian

Thomas R. Navin, Jr.

Executive Secretary and Clerk

ELSIE H. BISHOP

Assistant Executive Secretary
Members of the Council

Charies Francis Adams

Donald K. David

Wallace B. Donham

N. S. B. GrAS

JoHN W. HigarNs

JoH N C. KILEY

Henry L. Shattuck

The Society collects business manuscripts, books, and reports, distributes publications, and otherwise promotes research; the Harvard Graduate School of Business Administration furnishes space and also assistance from the members of its faculty and staff. The Harvard Business School Associates receive all the publications of the Society.

\section{BULLETIN OF THE BUSINESS HISTORICAL SOCIETY, INC.}

Henrietta M. Larson

Editor
ELSIE H. BISHOP Assistant Editor

Issued six times a year and sent free to members of the Society.

For further information concerning the Society or the Bulletin, address The Business Historical Society, Soldiers Field, Boston 63, Mass.

Copyright, 1946, by The Business Historical Society, Inc.

$\overline{\text { PRINTED IN U.S.A. }}$ 